\title{
THE ELIMINATION OF CHOLIC ACIDS. IV. IN PATIENTS WITH LIVER DISEASES ${ }^{1}$
}

\author{
BY BERTIL JOSEPHSON \\ (From the Department of Physiological Chemistry of Karolinsk Institutet and from the Medi- \\ cal Department II of Serafimerlasarettet, Stockholm, Sweden)
}

(Received for publication January 27, 1939)

This investigation was undertaken to study the rate of elimination of injected bile salts from the blood of patients with different types of liver disease.

In normal human subjects Josephson and Larsson (13) found that intravenously injected cholate disappeared from the blood very rapidly. Five minutes after the injection only a small part of the injected amount could be found in the blood and after thirty minutes the cholate concentration in the blood was normal again. In one hour most of the injected cholate had been excreted by the liver.

Corresponding results with normal animals had been previously reported by several investigators. This literature was briefly reviewed by Josephson, Jungner, and Rydin (11). On the other hand, Snell, Greene, and Rowntree (22) found that in animals with experimental obstructive jaundice disappearance of injected bile salts from the blood was very much delayed. Similar results were obtained later by Bollman and Mann (3) and by Chabrol, Cottet, and Sallet (6). Jungner, Rydin, and Josephson (14) studied the elimination from the blood of sodium cholate injected intravenously into animals with different experimental liver injuries. They found that the rate of disappearance was different in various kinds of jaundice. The elevation of the blood concentration after a cholate injection was, as one would expect, much greater in experimental jaundice than in normals. In most cases, however, the subsequent decrease was rather rapid in obstructive jaundice, but delayed in toxic hepatitis. The present investigation was carried out in order to determine whether corresponding results could be found in patients with liver diseases.

The spontaneous cholic acid concentration in the blood of patients with liver diseases has been the subject of many investigations $(2,5,15,16$,

\footnotetext{
1 This investigation was aided by a grant from the Foundation, "Therese och Johan Anderssons minne."
}

17, 21). All these workers used different methods and their results do not correspond. Usually cases of obstructive jaundice seem to have shown a high cholate concentration while cases with hepatitis and cirrhosis have given widely varying results. For this reason, determinations of the bile salt concentration in the blood have never been of clinical use.

Nakagawa, Simuro, and Suzuki (19) have tried to get a bile acid tolerance test by giving patients an injection of sodium dehydrocholate with subsequent analyses of the urine on substances precipitable by acetic acid. Their method, however, is not sufficiently specific to yield accurate data concerning bile acid excretion.

\section{METHODS}

The experiments were carried out on 62 patients in both medical departments of the Serafimer Hospital. They were divided into two groups. The first includes all cases with evidence of liver or bile duct involvement. The second group consists of control cases who had diseases in which liver involvement usually does not occur.

In the elimination tests pure sodium cholate was used. Ten ml. of a 0.52 per cent solution corresponding to 0.5 gram cholic acid, was injected into a cubital vein. The solution also contained 25 per cent glucose which prevents the pain usually caused by an intravenous injection of a pure cholate solution. No pains or symptoms were ever observed in connection with the injections. One blood sample for cholate analysis was taken before the injection. The subsequent samples were taken 5,30 , and 60 minutes after the injection in a vein on the opposite side than that where the injection was made. The cholic acid analyses were carried out with the method of Josephson $(10)^{2}$ as modified by Josephson and Larsson (13).

2 This method has been criticized by Jenke (9) who has claimed that it would be nonspecific at low concentrations 
The tests were carried out between 9 and 12 a.m. and all subjects were in the postabsorptive state. At the same time as the first blood sample for cholate analysis was taken other samples were drawn for the analysis of bilirubin (Jendrassik and Csike) and of the icterus index (Meulengracht). In addition to the routine tests on bile pigments and urobilin in the urine and feces and the Hay test in the urine, the galactose test (Brauer) was carried out in most cases and frequently also the Takata test. Other liver and blood tests of interest are not reported in the tables as they were carried out only occasionally.

\section{RESULTS}

A brief summary of the results obtained from the 27 control cases is given in Table I, showing that there was no marked difference between the

TABLE I

Patients without liver diseases. Concentration of cholic acids in blood before and after injection of $0.5 \mathrm{gram}$ of cholic acid

\begin{tabular}{|c|c|c|c|c|c|c|c|}
\hline & \multicolumn{4}{|c|}{$\begin{array}{l}\text { Cholate concentration in } \\
\text { blood }\end{array}$} & \multirow{2}{*}{\multicolumn{3}{|c|}{$\begin{array}{l}\text { Difference between } \\
\text { concentrations * }\end{array}$}} \\
\hline & \multirow{3}{*}{$\begin{array}{c}\text { I } \\
\begin{array}{c}\text { Before } \\
\text { injec- } \\
\text { tion }\end{array}\end{array}$} & \multicolumn{3}{|c|}{$\begin{array}{c}\text { Minutes after } \\
\text { injection }\end{array}$} & & & \\
\hline & & 5 & 30 & 60 & & & \\
\hline & & II & III & IV & II-I & II-III & III-I \\
\hline $\begin{array}{l}\text { Average..... } \\
\sigma \ldots \ldots . . . . . \\
\text { Maximum... } \\
\text { Minimum... }\end{array}$ & $\begin{array}{c}\text { mgm. } \\
\text { per } \\
100 \\
\text { ml. } \\
2.23 \\
0.84 \\
4.0 \\
0.9\end{array}$ & \begin{tabular}{|c} 
mgm. \\
per \\
100 \\
$m l$. \\
4.40 \\
\\
6.7 \\
2.2
\end{tabular} & $\begin{array}{c}\text { mgm. } \\
\text { per } \\
100 \\
\text { ml. } \\
2.47 \\
\\
4.7 \\
0.9\end{array}$ & $\begin{array}{c}\text { mgm. } \\
\text { per } \\
100 \\
\text { ml. } \\
2.47 \\
\\
4.6 \\
0.2\end{array}$ & $\begin{array}{l}2.06 \\
1.23 \\
4.8 \\
0.4\end{array}$ & $\begin{array}{l}1.93 \\
1.19 \\
4.2 \\
0.2\end{array}$ & $\begin{array}{r}0.21 \\
0.65 \\
+1.8 \\
-1.0\end{array}$ \\
\hline
\end{tabular}

* The sums of and differences between the different averages do not correspond correctly as one value is missing in a few series.

and erroneous at high. According to Josephson's studies (10), it is very probable that the method is specific for cholic acids in blood, but it may be admitted that this is not definitely proved. In this investigation and those of Josephson and collaborators, a nonspecific reaction has no influence on the results, as they deal with comparisons of the concentration over a short period of time in single individuals after addition of pure cholates. For higher concentrations of a degree occurring in jaundice before and after cholate injections, the method has been shown by Josephson to give very satisfactory results. This has been confirmed in this laboratory. elimination rate in these cases and that in normal cases receiving twice this amount of cholate, as described by Josephson and Larsson (13). The elevation of the blood cholates 5 minutes after the injection was much less than would be expected by dilution in the total volume of the blood. The rate of disappearance of the cholates was more rapid than that of other liver active substances, e.g., bromsulphalein (18). As the 5-minute samples were taken during the rapid decrease of the blood cholates it was quite natural that the concentrations found, and the differences between these and other values should show great variations. After 30 minutes the cholate concentration was normal again.

Three of these cases showing values within the normal limits were treated for severe thyrotoxicosis. This may be of interest in connection with an investigation by Schmidt (20) showing that in rabbits treated with thyroxin, the elimination of injected cholates was considerably delayed. It is also well known that other liver function tests often give pathological values in cases of hyperthyroidism (literature reviewed by Bartels (1)).

The results from the patients with liver symptoms are shown in Tables II to V.

To some degree the original cholate concentration in the blood of these patients corresponded to the degree of jaundice, but there were several exceptions. No difference could be found between the concentration in different kinds of jaundice. In the cases with carcinoma, cirrhosis, or congestion of the liver without jaundice there was no elevation. The concentration was also normal in a few cases with jaundice. The tests in Cases 14,15 , and 20 with hepatitis were carried out during the recovery periods which explains the normal values.

The elevation of the cholates after the injection varied widely but was increased in jaundice and highest in the most jaundiced cases.

The subsequent decrease showed interesting characteristics. In cases with liver tumors the decrease was nearly as rapid as in normals. As a rule, the difference between the 5-minute and the 30 -minute values was above $2.2 \mathrm{mgm}$. per $100 \mathrm{ml}$. There were two exceptions. Case 1, in addition to the obstructive jaundice, had an acute cholangeitis with multiple abscesses and extensive destruction of the liver parenchyma; and Case 4 had no 


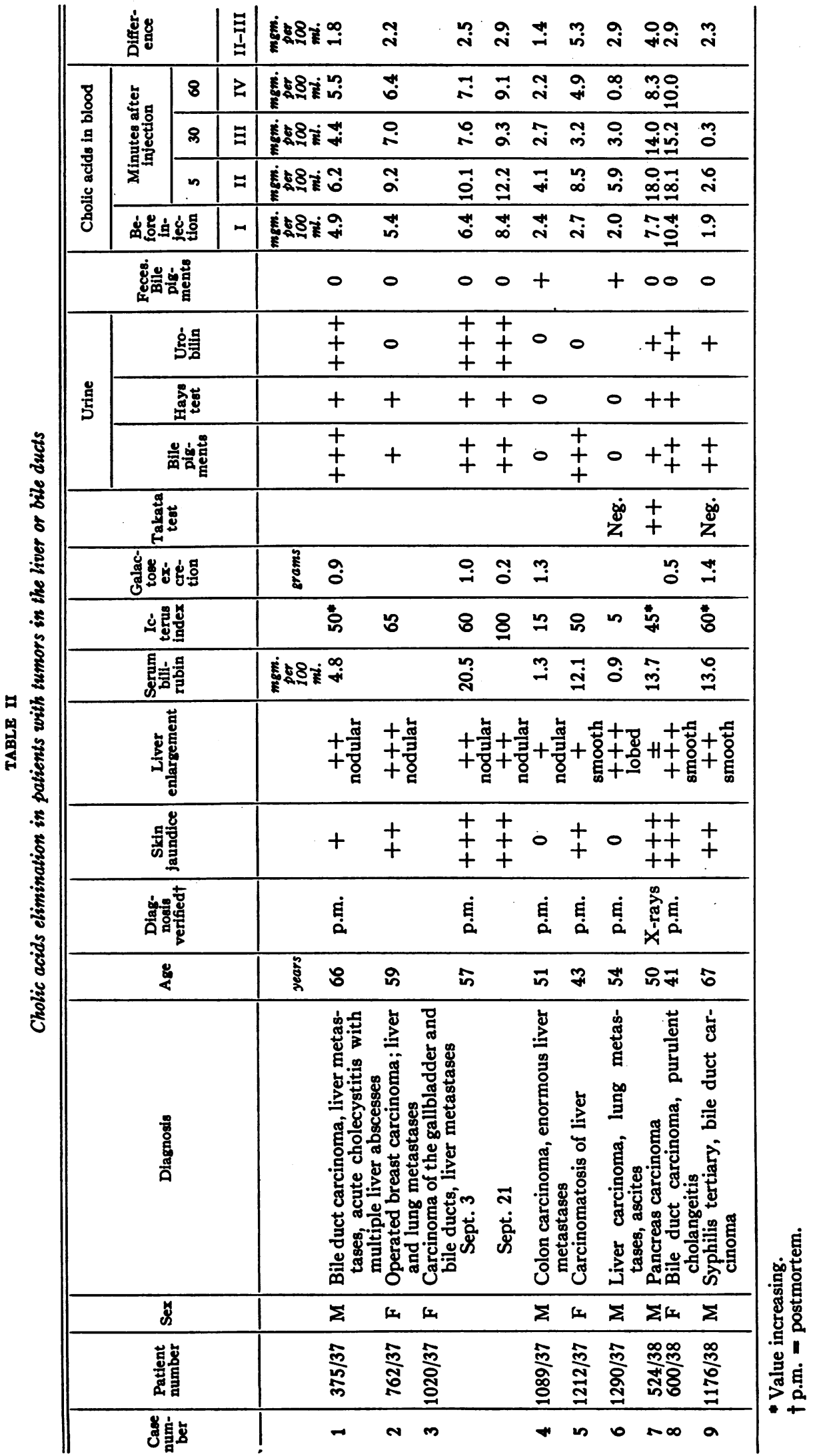


BERTIL JOSEPHSON

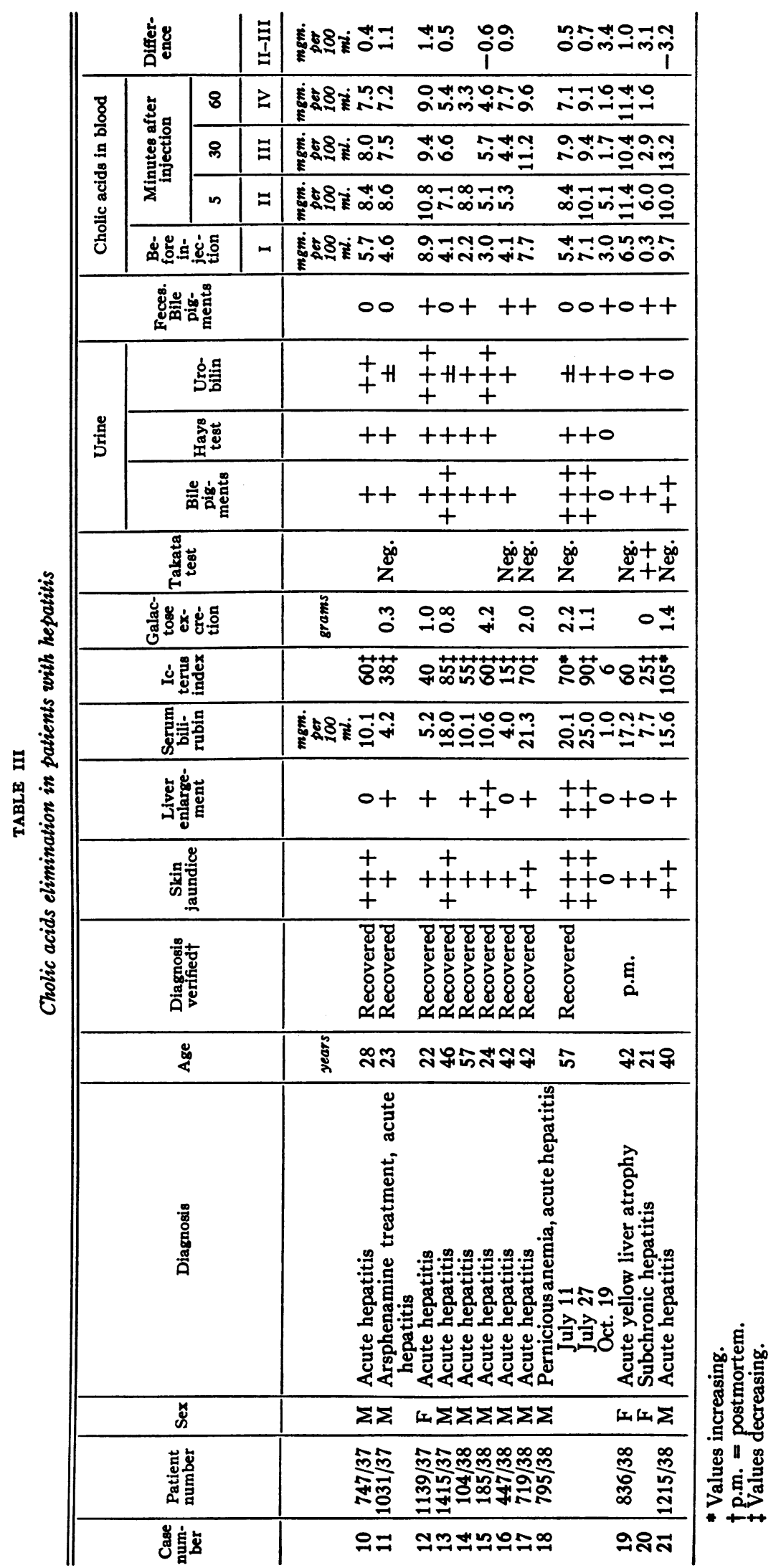




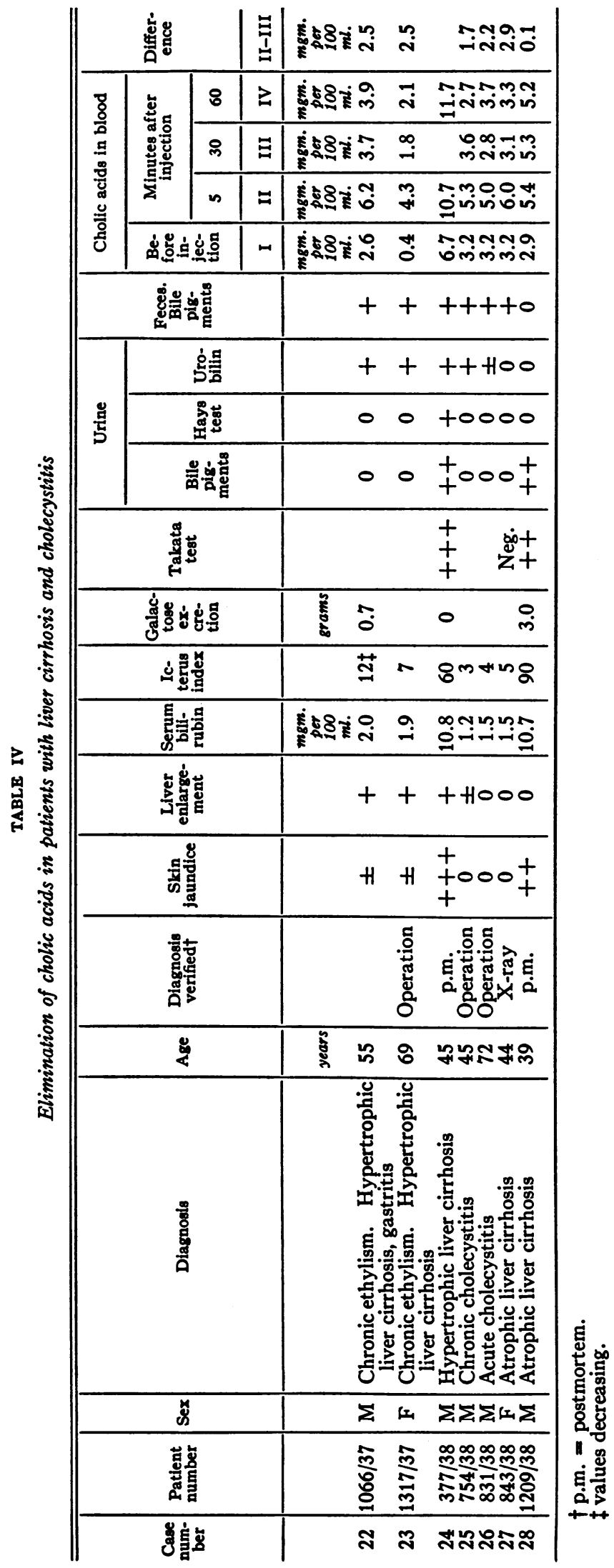




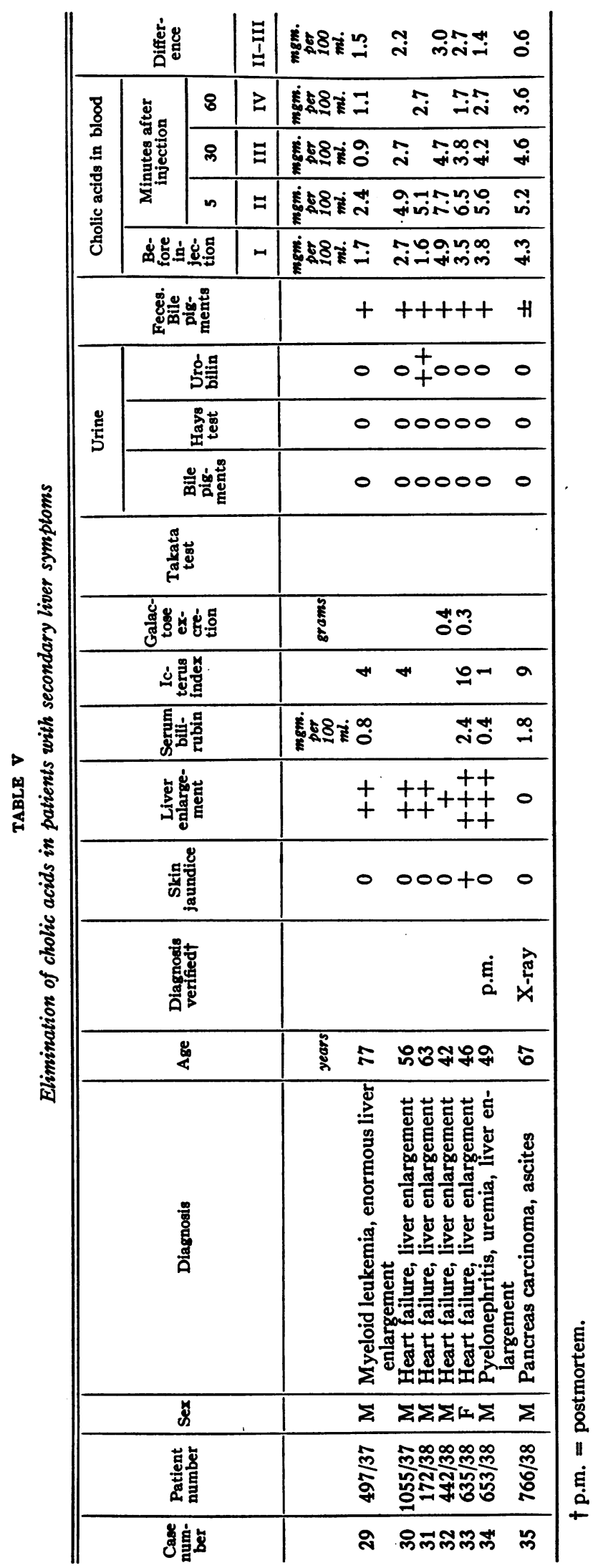


signs of biliary obstruction and a normal elimination curve.

In acute hepatitis the decrease was much slower; in Case 11 the difference between the 5minute and the 30 -minute value was 1.1 , and in Case 12, 1.4, but in other cases it was not over 0.9 mgm. per $100 \mathrm{ml}$. Case 20 with subchronic hepatitis later developed a biliary cirrhosis with ascites.

Two cases of cholecystitis and the cases with liver edema showed normal elimination curves. One case of cirrhosis with severe jaundice had an elimination curve of the hepatitis type. Other cases with cirrhosis reacted normally.

The elimination curves did not correspond to the other liver tests.

The sharp difference between the elimination curves in jaundice due to obstruction and in hepatitis corresponds very well to the results of Jungner, Rydin, and Josephson (14). This difference was found even more regularly in human cases of liver diseases than it was in the animals with experimental jaundice. It is possible that the first disappearance from the blood of the major part of the injected cholates was due to adsorption of the bile acids to tissues other than the liver. The subsequent sharp decrease in cases of obstruction could be referred to absorption by a still functioning liver parenchyma, according to Bollman and Mann (4) and Chabrol, Cottet, and Sallet (7). Following this first decrease a slight increase one hour after the injection was observed in some cases. This could be due to a partly maintained circulation of the bile salts by the aid of the lymph vessels of the liver as in experimental obstructive jaundice (12). The existence of such a short circuit of the bile circulation in obstructive jaundice is also supported by the recent experiments of Doubilet (8) who recovered bile pigments in the thoracic lymph of dogs a few minutes after applying slight pressure in the bile ducts. In hepatitis, the absorbing function of the liver is diminished and consequently those bile salts which are not adsorbed by other tissues remain in the blood and the decrease is slow.

\section{SUM MARY}

In jaundice, the increase of the cholic acid content in the blood after an injection of sodium cholate is greater than in normals. It is not greater in liver diseases without jaundice. The subsequent decrease is delayed in acute hepatitis, but not in jaundice due to obstruction of the bile ducts. A cholic acid elimination test seems to be valuable in the differential diagnosis between these two kinds of jaundice.

\section{BIBLIOGRAPHY}

1. Bartels, E., Liver function in hyperthyroidism as determined by the hippuric acid test. Ann. Int. Med., 1938, 12, 652.

2. Boku, S., and Gon, K., Studien über die Gallensäuren; über das Verhalten der Blutgallensäuren bei Leberund Gallengangskrankheiten. J. Chosen M. A., 1933, 23, 87.

3. Bollman, J., and Mann, F., Alterations in hepatic function produced by experimental hepatic lesions. Ann. Int. Med., 1935, 9, 617.

4. Bollman, J., and Mann, F., The influence of the liver on the formation and destruction of bile salts. Am. J. Physiol., 1936, 116, 214.

5. Chabrol E., Charonnat, R., and Cottet, J., La recherche des sels biliaires dans le sérum sanguin par la réaction phospho-vanilique. Compt. rend. Soc. de biol., 1934, 115, 835.

6. Chabrol, E., Cottet, J., and Sallet, J., Recherches comparatives sur le pouvoir de concentration du foie et du rein vis à vis de l'acide cholalique. Compt. rend. Soc. de biol., 1936, 122, 184.

7. Chabrol, E., Cottet, J., and Sallet, J., Recherches sur l'enrichissement du foie et du muscle en acide cholalique au cours des cholalémies expérimentales. Compt. rend. Soc. de biol. 1936, 122, 186.

8. Doubilet, H., Personal communication, 1939.

9. Jenke, M., Zwei neue spektrochemische Verfahren zum Nachweis und zur quantitativen Bestimmung von Gallensäuren in Blut, Stuhl und Urin. Verhandl. d. deutsch. Gesellsch. f. inn. Med., 1937, 49, 246.

10. Josephson, B., The determination of cholic acids in blood. Biochem. J., 1935, 29, 1519.

11. Josephson, B., Jungner, G., and Rydin, A., Elimination of cholic acids. I. In healthy animals. Acta med. Scandinav., 1938, 97, 237.

12. Josephson, B., and Kaunitz, H., Die Resorbtion der Gallensäuren bei experimentellem Icterus. Ztschr. f. d. ges. exper. Med., 1937, 102, 195.

13. Josephson, B., and Larsson, H., Elimination of cholic acids. III. In man. Acta med. Scandinav., 1939, 99, 140.

14. Jungner, G., Rydin, A., and Josephson, B., Elimination of cholic acids. II. In experimental jaundice. Acta med. Scandinav., 1938, 97, 254.

15. Katayama, I. Bile acids in jaundice. Arch. Int. Med., 1928, 42, 916.

16. Kaunitz, H., and Kent, H., Ueber die klinische Bedeutung von Veränderungen der Oberflächenspan- 
nung des Blutserums. Ztschr. f. klin. Med., 1936, $131,285$.

17. Lichtman, S., A new procedure for the estimation of bile salts in body fluids based on bile salt hemolysis. J. Biol. Chem., 1934, 107, 717.

18. Mills, M., and Dragstedt, C., Removal of intravenously injected bromsulphalein from the blood stream of the dog. Arch. Int. Med., 1938, 62, 216.

19. Nakagawa, S., Simuro, S., and Suzuki, S., Gallensäurebelastungsprobe zur Leberfunktionsprüfung. Klin. Wchnschr., 1934, 13, 1392.
20. Schmidt, L. H., The removal of sodium cholate from the blood and its secretion into the bile as affected by thyroxine. Am. J. Physiol., 1937, 120, 75.

21. Snell, A., Clinical aspects of portal cirrhosis. Ann. Int. Med., 1931, 5, 338.

22. Snell, A., Greene, C., and Rowntree, L., Diseases of the liver: further studies in experimental obstructive jaundice. Arch. Int. Med., 1927, 40, 471.

23. Snell, A., and Magath, T., The use and interpretation of tests for liver function. J. A. M. A., 1938, $110,167$. 